\title{
International Applications for Floating Solar Photovoltaics
}

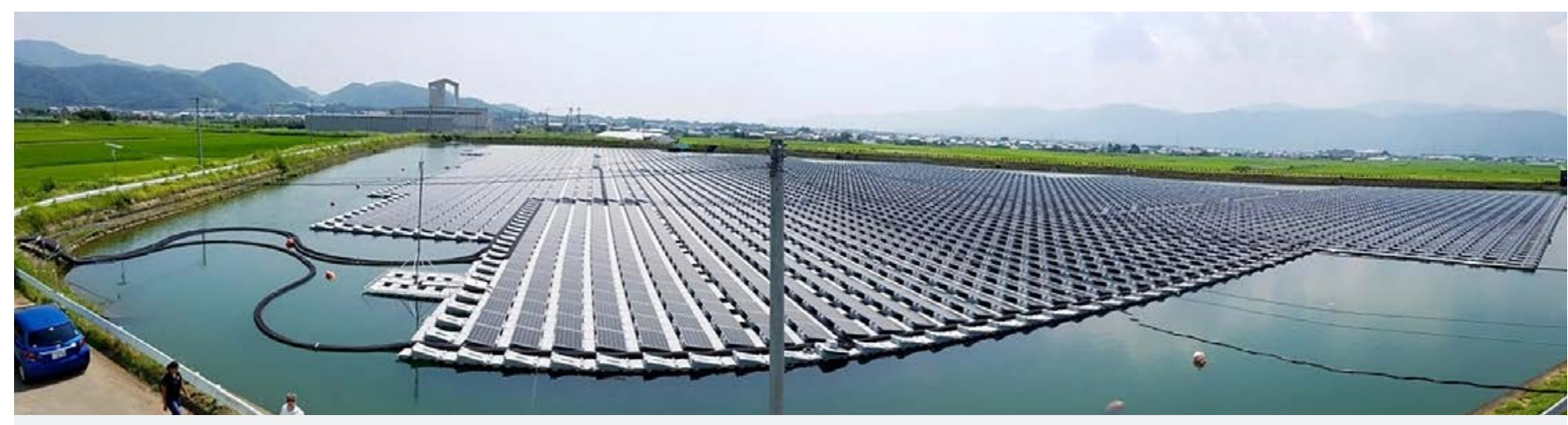

To ensure reliable, affordable, and sustainable future power supplies, many developing countries are exploring options for new electricity generation. Floating solar photovoltaics (FPV) are becoming an increasingly competitive option; however, the technology is still nascent, and many potential adopters have questions about the underlying technology, its benefits, and how to analyze it appropriately. The U.S. Department of Energy's National Renewable Energy Laboratory (NREL) is a leader in FPV and is looking to develop international implementation, analysis, and research collaborations to further advance the technology and support global deployment. This concept note provides an overview of FPV and potential areas of collaboration. ${ }^{1}$

\section{What are Floating Solar Photovoltaics, and Why are They Interesting?}

FPV systems represent an emerging opportunity in which solar photovoltaic (PV) systems are sited directly on water bodies, such as lakes, ponds, or reservoirs. Technological advances and the falling capital costs of PV modules have dramatically increased the cost competitiveness of solar energy over the last several years (IRENA 2018). Specific interest in FPV has grown because of competing landuse pressures, renewable energy and energy security goals, power sector resilience motivations, and other benefits associated with FPV.
To date, FPV has predominantly been installed on artificial water bodies (e.g., treated wastewater storage ponds, reservoirs, and agricultural irrigation or retention ponds). The PV module technology deployed with FPV is similar to traditional ground-or-roof-mounted systems, but the modules are mounted on a floating platform made of plastic and stainless steel (Sahu, Yadav, and Sudhakar 2016; Pickerel 2016; Choi 2014; Choi, Lee, and Kim 2013; Redón Santafé et al. 2014). Typically, multiple floating platforms are connected with designated walkways to allow access for operation and maintenance. These connected floating platforms are anchored to the shore, to the bottom of the water body, or to floating anchors. The main electrical equipment resides onshore, and electricity is transmitted from the FPV system to this equipment and the grid or load via underwater cables (Trapani and Redón Santafé 2015; Sahu, Yadav, and Sudhakar 2016; Krishnaveni, Anbarasu, and Vigneshkumar 2016).

\section{Where, When, and How are Floating Solar Photovoltaics Being Deployed?}

FPV systems are commercially available, and the deployment of FPV is accelerating worldwide. The first commercial FPV installation came online in 2007 at the Far Niente Winery in California, yet the vast majority of existing systems have become operational since 2014 (Trapani and 
Redón Santafé 2015; Minamino 2016). Global installed capacity has grown from approximately $10 \mathrm{MW}$ in 2014 to near 1,100 MW by mid-2018 (Figure 1) (World Bank Group, ESMAP, and SERIS 2018). Primary markets include Japan and the United States; however, FPV systems have been installed throughout Southeast Asia, Europe, and the Middle East. System sizes installed to date vary and range from approximately $4 \mathrm{~kW}$ to $40 \mathrm{MW}$ (Trapani and Redón Santafé 2015; Sahu, Yadav, and Sudhakar 2016; Mesbahi and Minamino 2018; Daley 2017).

Based on available surface area of artificial water bodies worldwide and system assumptions, the World Bank and the Solar Energy Research Institute of Singapore (SERIS) estimate global technical potential of FPV may range from $400 \mathrm{GW}$ to $1,000 \mathrm{GW}$. The FPV market is expected to grow globally from $\$ 13.8$ million in 2015 to $\$ 2.7$ billion by 2025 (Grand View Research 2017). Currently, FPV system costs (in terms of U.S. dollars per watt and levelized cost of energy) are slightly higher than land-based equivalents (not including additional benefits of FPV), but costs are expected to decline (World Bank Group, ESMAP, and SERIS 2018).

Research about the performance of FPV systems is nascent, but these systems have been of significant interest recently due to claims of benefits for both water managers and power sector stakeholders. The private sector leads the development and deployment of FPV technologies, with the research community showing increased interest. Still, many questions about FPV remain unanswered. Stakeholders need trusted, timely information to take advantage of this emerging technology. This leaves many potential opportunities for

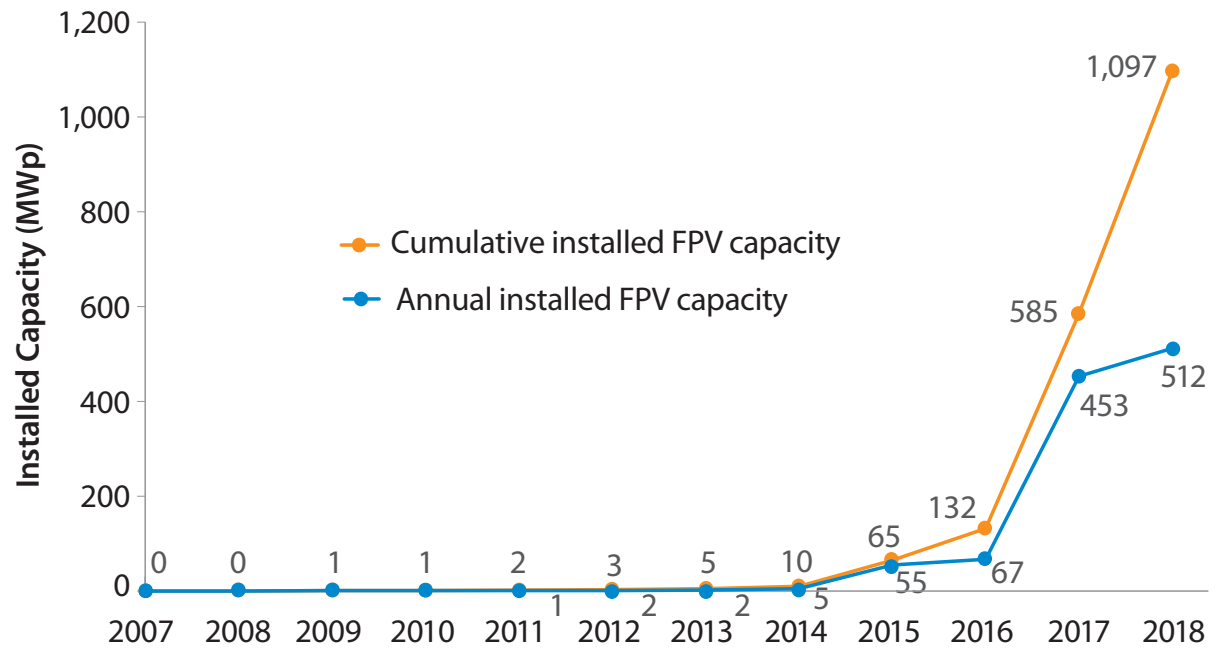

Figure 1. Global installed capacity of FPV in MW

Source: World Bank Group, ESMAP, and SERIS 2018

\section{Box 1. Benefits of Floating Solar Photovoltaics Integration}

Utility-scale solar PV often requires significant parcels of land; however, land-constrained developing countries may have to prioritize land use for agricultural, forestry, or other needs. FPV may offer alternatives to scale up renewables and reduce competing land-use pressures by co-locating solar PV systems on artificial water bodies like reservoirs. In addition to generation, FPV may offer the following power system benefits, particularly when sited with existing hydropower:
- Avoiding land-energy conflicts (e.g., energy versus food concerns for land-use designation)

- Lowering land acquisition and site preparation costs

- Gaining potential system efficiency and production due to temperature-regulating effect of water;

- Improving solar PV performance due to reduced shading effects

- Increasing panel density for a given area (larger installed capacity per unit area)
- Power system benefits and reducing capital costs when co-located with hydropower

- Reducing costs for waterbody maintenance due to decreased algae growth

- Reducing rates of water evaporation and increasing available water for other uses

- Converting potentially underused revenue-generating use. space into areas that allow for

Sources: Hernandez et al. 2014; Hoffacker, Allen, and Hernandez 2017; Ibeke et al. 2017; Cazzaniga et al. 2018; Spencer et al. 2018Allen, and Hernandez 2017; Ibeke et al. 2017; Cazzaniga et al. 2018; Spencer et al. 2018 


\section{Analysis}

- How does FPV impact power system operations, and what benefits does it provide?

- What are the costs and benefits of co-locating FPV with hydropower?

- What tools can be developed for FPV analysis, or how can existing tools be used?

\section{Implementation}

- Identify FPV investment opportunities and technical potential in a given area.

- Conduct a techno-economic assessment of potential projects using NREL's established methodology.

- Identify unique regulatory and policy issues that need to be addressed for deployment.

\section{Monitoring and Evaluation}

- Monitor existing systems to document system output performance benefits.

- Validate and quantify the environmental benefits of FPV related to reduced water evaporation and reduced algal growth.
Technology Research

- Research and development of built-for-purpose PV and supporting systems for FPV

- Explore FPV system designs that reduce equipment weathering and erosion. analysis, implementation, monitoring and evaluation, and technology research collaborations as shown in Figure 2.

\section{How Can We Collaborate on Floating Solar Photovoltaics?}

NREL has significant, internationally renowned expertise in solar PV material science, techno-economic analysis, grid integration, and system design that it can bring to critical FPV research, analysis, and implementation questions. For example, NREL researchers recently published a national assessment of the technical potential of FPV systems on artificial water bodies in the United States, establishing an adaptable methodology that could support similar assessments worldwide. Through this spatial approach, researchers identified approximately 21,961 square kilometers of suitable man-made bodies of water for deployment that could potentially support 2.1 terawatts of installed FPV and produce an annual 786 terawatthours of electricity (Spencer et al. 2018). In partnership with the Colorado Energy Office and floating solar developer Ciel e Terre, NREL is evaluating FPV opportunities in Colorado.
In addition to working domestically, NREL is supporting countries around the globe with significant hydropower capacity and high-quality solar resources to advance development and use of renewable energy. This includes work in Brazil, Colombia, Ghana, India, Kazakhstan, Laos, Tajikistan, and Vietnam, among others (NREL 2018; USAID-NREL Partnership 2019).

\section{The Future of Floating Solar Photovoltaics}

Continued work on FPV should advance an emerging global application of solar PV and would offer multiple benefits to stakeholders, such as diversity of generation, increased investment opportunities, and economic development.

\section{Contact}

Samuel Booth

National Renewable Energy Laboratory

Tel: +1 303-275-4625

Email: Samuel.Booth@nrel.gov

Written by Alexandra Aznar, Nathan Lee, and Samuel Booth, National Renewable Energy Laboratory

\section{References}

Cazzaniga, R., M. Cicu, M. RosaClot, P. Rosa-Clot, G. M. Tina, and C. Ventura. 2018. "Floating Photovoltaic Plants: Performance Analysis and Design Solutions." Renewable and Sustainable Energy Reviews 81 (January): 1730-41. https://doi.org/ 10.1016/j.rser.2017.05.269.

Choi, Young-Kwan. 2014. "A Study on Power Generation Analysis of Floating PV System Considering Environmental Impact." International Journal of Software Engineering and Its Applications 8, no. 1: 75-84. https://doi. org/10.14257/ijseia.2014.8.1.07.

Choi, Young-Kwan, Nam-Hyung Lee, and Kern-Joong Kim. 2013. "Empirical Research on the Efficiency of Floating PV Systems Compared with Overland PV Systems." In Proceedings, The 3rd International Conference on Circuits, Control, Communication, Electricity, Electronics, Energy, System, Signal and Simulation, 25:284-289.

Daley, Jason. 2017. "China Turns on the World's Largest Floating Solar Farm." Smart News | Smithsonian. June 7, 2017. https://www.smithsonianmag.com/ smart-news/china-launches-largestfloating-solar-farm-180963587/. 
Grand View Research. 2017. "Floating Solar Panels Market Size \& Share |Industry Report, 2018-2025.” https:// www.grandviewresearch.com/industryanalysis/floating-solar-panels-market.

Hernandez, R. R., S. B. Easter, M. L. Murphy-Mariscal, F. T. Maestre, M. Tavassoli, E. B. Allen, C. W. Barrows, et al. 2014. "Environmental Impacts of Utility-Scale Solar Energy.” Renewable and Sustainable Energy Reviews 29 (January): 766-79. https://doi.org/ 10.1016/j.rser.2013.08.041.

Hoffacker, Madison K., Michael F. Allen, and Rebecca R. Hernandez. 2017. "Land-Sparing Opportunities for Solar Energy Development in Agricultural Landscapes: A Case Study of the Great Central Valley, CA, United States." Environmental Science \& Technology 51, no. 24: 14472-82. https://doi.org/ 10.1021/acs.est.7b05110.

Ibeke, Mfon, Emily Miller, Dylan Sarkisian, Jessica Gold, Sydney Johnson, and Kester Wade. 2017. "Floating Photovoltaics in California Project Final Report | Tomkat.” August 2017. https://tomkat.stanford.edu/ floating-photovoltaics-california-projectfinal-report.

IRENA. 2018. "Renewable Power Generation Costs in 2017." Abu Dhabi: International Renewable Energy Agency (IRENA). http://irena.org/ publications/2018/Jan/Renewablepower-generation-costs-in-2017.
Krishnaveni, N, P Anbarasu, and D. Vigneshkumar. 2016. "A Survey on Floating Solar Power System." International Journal of Current Research and Modern Education. http://ijcrme.rdmodernresearch.com/ wp-content/uploads/2015/06/CP-024.pdf.

Mesbahi, Mina, and Saori Minamino. 2018. "Solarplaza Top 70 Floating Solar PV Plants.” January 3, 2018. https:// www.solarplaza.com/channels/top10s/11761/top-70-floating-solarpv-plants/.

Minamino, Saori. 2016. "Floating Solar Plants: Niche Rising to the Surface?" Solar Asset Management: North America. November 11, 2016. https://solarassetmanagement.us/ news-source/floating-plants-article.

NREL. 2018. "International Activities: Country Programs." National Renewable Energy Laboratory (NREL). 2018. https:/www.nrel.gov/international/ country-programs.html.

Pickerel, Kelly. 2016. "What to Consider When Installing a Floating Solar Array." Solar Power World. June 13, 2016. https://www.solarpowerworldonline. com/2016/06/consider-installingfloating-solar-array/.

Redón Santafé, Miguel, Juan Bautista Torregrosa Soler, Francisco Javier Sánchez Romero, Pablo S. Ferrer Gisbert, José Javier Ferrán Gozálvez, and Carlos M. Ferrer Gisbert. 2014. "Theoretical and Experimental Analysis of a Floating Photovoltaic Cover for Water Irrigation Reservoirs." Energy 67 (April): 246-55. https://doi.org/ 10.1016/j.energy.2014.01.083.
Sahu, Alok, Neha Yadav, and K. Sudhakar. 2016. "Floating Photovoltaic Power Plant: A Review." Renewable and Sustainable Energy Reviews 66 (December): 815-24. https://doi.org/ 10.1016/j.rser.2016.08.051.

Spencer, Robert S., Jordan Macknick, Alexandra Aznar, Adam Warren, and Matthew O. Reese. 2018. "Floating Photovoltaic Systems: Assessing the Technical Potential of Photovoltaic Systems on Man-Made Water Bodies in the Continental United States." Environmental Science \& Technology, December. https://doi.org/10.1021/acs. est.8b04735.

Trapani, Kim, and Miguel Redón Santafé. 2015. "A Review of Floating Photovoltaic Installations: 2007-2013." Progress in Photovoltaics: Research and Applications 23, no. 4: 524-32. https://doi.org/10.1002/pip.2466.

USAID-NREL Partnership. 2019. "Delivering Clean, Reliable, and Affordable Power in the Developing World." National Renewable Energy Laboratory: USAID-NREL Partnership. 2019. https://www.nrel.gov/usaidpartnership/.

World Bank Group, ESMAP, and SERIS. 2018. "Where Sun Meets Water: Floating Solar Market Report - Executive Summary." 131291. The World Bank. http:// documents.worldbank.org/curated/ en/579941540407455831/Where-SunMeets-Water-Floating-Solar-MarketReport-Executive-Summary. 